\title{
Hydrostatic Pressure Resistance of 14 Genera of Microbes under Controlled Room Temperature
}

\author{
Takashi OKAZAKI ${ }^{1}$ and Norihiko MATSUDA ${ }^{2}$ \\ ${ }^{1}$ Hiroshima Prefectural Food Technology Research Center, 12-17 Hijiyamahonmachi, Minami-ku, Hiroshima 732, Japan \\ ${ }^{2}$ Japan Canncers Association, Research Laboratory, 2-5-3 Fukuura, Kanazawa-ku, Yokohama 236-0004, Japan
}

Received March 2, 1998; Accepted June 19, 1998

The pressure resistance of microbes (14 genera) was investigated at pressures ranging from $300 \mathrm{MPa}$ to 500 $\mathrm{MPa}$ at $20^{\circ} \mathrm{C}$ for $20 \mathrm{~min}$ using a compact pressure vessel. Acinetobacter sp., Pseudomonas fluorescens and Vibrio parahaemolyticus, all of which are gram negative bacteria, and Saccharomyces cerevisiae were dead at $300 \mathrm{MPa}$, although gram positive bacteria were all alive at that pressure. At $400 \mathrm{MPa}$, Salmonella Typhimurium, Morganella morganii, Leuconostoc mesenteroides, and Candida parapsilosis were dead. At 500 MPa, Escherichia coli and Lactobacillus plantarum were dead. However, Staphylococcus aureus, Enterococcus faecalis, Corynebacterium sp., and Neosartorya hiratsukae (ascospores) survived even at $500 \mathrm{MPa}$, and the organisms except for $N$. hiratsukae were all gram positive bacteria.

Keywords: high pressure, sterilization, pressure resistance, $E$. coli

High hydrostatic pressure was applied to sterilization of microbes for the first time by Hite (1899). Nearly a century later, high hydrostatic pressure as one of the food processing techniques was investigated widely by Hayashi (1989). Especially, the pressure treatment has been recognized as a sterilization technique without heating, and many reports have been presented on it. Some of the reports indicated that the temperature during pressurizing significantly affects the inactivation of organisms even at the room temperatures (Horie et al, 1992; Okazaki et al., 1996). In addition, it is known that the pressurizing temperature rises as a result of adiabatic compression, which probably affects the inactivation of organisms by high pressure. In spite of the presence of this problem, there have rarely been such reports in which the temperature histories during the pressure treatment were indicated.

Thus, the object of this study is to clarify the pressure resistance of various microbes under the controlled and monitored temperature. A compact pressure vessel capable of easily controlling the sample temperature and of recording the change in the temperature during the pressure treatment was used for this purpose. Using this vessel, the pressure resistance of 14 genera of microorganisms was measured.

\section{Materials and Methods}

Test microbes Escherichia coli (IAM 1253), Staphylococcus aureus (209P), Lactobacillus plantarum (IAM 1216), Pseudomonas fluorescens (IAM 12022), Leuconostoc mesemteroides (IAM 1046), Enterococcus faecalis (IFO 8033), Saccharomyces cerevisiae (IAM 4954) and Candida parapsilosis (IFO 10564) were used. Furthermore, Salmonella typhimurium, Morganella morganii, Vibrio parahaemolyticus, and Acinetobacter sp., all of which were obtained from the Department of Food Science and Technology, Tokyo
University of Fisheries, Corynebacterium sp. derived from the Tokyo Metropolitan Food Technology Research Center, and Neosartorya hiratsukae (isolated from spoiled drink) were also used.

Pressurizing unit The unit previously described was used (Okazaki et al, 1994).

Preparation of microbial suspension A certain number of the strain cells ( $E$. coli, $S$. typhimurium, S. aureus, $M$. morganii, P. fluorescens, Acinetobacter sp., and Corynebacterium sp.) was inoculated into glucose broth, which consists of meat extract $3 \mathrm{~g}$ (Oxoid, England), yeast extract $3 \mathrm{~g}$ (Nihon-seiyaku, Tokyo), bacto peptone $10 \mathrm{~g}$ (Difco Laboratories, Detroit, Mich.) and glucose $5 \mathrm{~g} / l, \mathrm{pH}$ 7.0. V. parahaemolyticus was inoculated into glucose broth $+3 \% \mathrm{NaCl}$, and L. plantarum, L. mesenteroides and E. faecalis were inoculated into Man Rogosa Sharpe media (MRS, Oxoid, England). S. cerevisiae and $C$. parapsilosis were inoculated into malt extract broth (Difco Laboratories). Incubation temperatures were the following: $E$. coli, $S$. typhimurium, $S$. aureus and $E$. faecalis at $35^{\circ} \mathrm{C}$, Acinetobacter sp., $M$. morganii, L. plantarum, L. mesenteroides, S. cerevisiae and Corynebacterium sp. at $30^{\circ} \mathrm{C}$, and $P$. flourescens and $C$. parapsilosis at $25^{\circ} \mathrm{C}$ for $1-4$ days until these microbes grow sufficiently. After $N$. hiratsukae was incubated on a potato dextrose agar (PDA, Nissui-seiyaku, Tokyo) at $30^{\circ} \mathrm{C}$ for 100 days, the plates were homogenized with sterile distilled water for a few minutes, and then the homogenized suspension containing ascospores was gained. These microbial cultures had been stored at $5^{\circ} \mathrm{C}$. Each microbial culture was diluted with 10 volumes of the same medium used for the incubation, just before usage to produce a microbial suspension.

Procedure for pressurizing microbe A 1.2-ml of the microbial suspension was poured in a sample container (a $4 \times$ $100-\mathrm{mm}$ sterile silicone rubber tube sealed at one end) 
without air bubbles, and the open end of the container was closed with a silicone rubber plug. The sample container filled with the suspension was inserted in a pressure vessel, which was immersed in a water bath (Thermo minder H-100, TAITEC Ltd., Koshigaya) controlled accurately at temperatures ranging from $10^{\circ} \mathrm{C}$ to $50^{\circ} \mathrm{C}$ for $5 \mathrm{~min}$ to make sure the initial temperature of each sample suspension was regulated to the same level. After that, the vessel was pressurized at $100^{-}$ $500 \mathrm{MPa}$ for $10 \mathrm{~min}$ to $40 \mathrm{~min}$. It took about $30 \mathrm{~s}$ to reach 400 $\mathrm{MPa}$ and about $15 \mathrm{~s}$ to return to atmospheric pressure.

Measurement of temperature A thermocouple (CA, $1.5 \mathrm{~mm} \phi$ ) was fixed in the center of a sample container to measure the temperature changes in the microbial suspensions, which were recorded as the digital data per $5 \mathrm{~s}$ during the pressure treatments.

Survival microbial cell count The pressurized tubes were aseptically opened, and the contents were withdrawn from each for plating. After cultivation at $35^{\circ} \mathrm{C}$ for 2 days, the colony growing on agar plates was enumerated. The plates used were the following: standard agar $+3 \% \mathrm{NaCl}$ for $V$. parahaemolyticus, MRS for L. plantarum, L. mesenteroides and $E$. faecalis, DPA for fungi, and standard agar for other microbes.

Assessment of pressurized sterilization The pressurized content $(0.2 \mathrm{ml})$ in each tube was aseptically poured into $4 \mathrm{ml}$ of broth medium in 5 test tubes, respectively. When the organisms did not grow in all of the 5 test tubes after 7 days, they were judged to be sterilized.

\section{Results and Discussion}

The effect of incubation time on the growth of $E$. coli cells pressurized at $30^{\circ} \mathrm{C}$ is shown in Table 1 . The organism pressurized at both $100 \mathrm{MPa}$ and $200 \mathrm{MPa}$ grew during every treatment time after incubation for only a day. The organism treated at $300 \mathrm{MPa}$ for $5 \mathrm{~min}$ and $10 \mathrm{~min}$ also grew for a day, although pressurization for longer than $15 \mathrm{~min}$ resulted in no growth of the organism. However, when the incubation time

Table 1. Effect of incubation time on growth of pressurized E. coli cells.

\begin{tabular}{cccccccc}
\hline \multirow{2}{*}{$\begin{array}{c}\text { Inc. time } \\
\text { (days) }\end{array}$} & $\begin{array}{c}\text { Pressure } \\
(\mathrm{MPa})\end{array}$ & 5 & 10 & 15 & 20 & 30 & 40 \\
\cline { 3 - 7 } & 100 & $5^{b)}$ & 5 & 5 & 5 & 5 & 5 \\
& 200 & 5 & 5 & 5 & 5 & 5 & 5 \\
& 300 & 5 & 1 & 0 & 0 & 0 & 0 \\
& 400 & 0 & 0 & 0 & 0 & $-c)$ & - \\
2 & 300 & 5 & 5 & 5 & 5 & 5 & 0 \\
& 400 & 0 & 0 & 0 & 0 & - & - \\
4 & 300 & 5 & 5 & 5 & 5 & 5 & 1 \\
& 400 & 1 & 0 & 0 & 0 & - & - \\
7 & 300 & 5 & 5 & 5 & 5 & 5 & 1 \\
& 400 & 2 & 0 & 0 & 0 & - & - \\
& 300 & 5 & 5 & 5 & 5 & 5 & 1 \\
\hline \multirow{2}{*}{15} & 400 & 2 & 0 & 0 & 0 & - & - \\
\hline
\end{tabular}

E. coli cells, $4.6 \times 10^{7} \mathrm{CFU} / \mathrm{ml}$, suspended in glucose broth were pressurized at $30^{\circ} \mathrm{C}$ and were subcultured at $35^{\circ} \mathrm{C}$. The number of sample tubes subcultured was 5 per set.

a) Incubation time.

${ }^{b)}$ Number of positive growth tubes.

c) Not examined. was prolonged for 4 days, the organism grew even during the treatment for $40 \mathrm{~min}$. Furthermore, the organism pressurized at $400 \mathrm{MPa}$ for $5 \mathrm{~min}$ grew only after incubation for 4 days. After incubation for 7 days and 15 days, the number of the growth tubes no longer increased. Based on these results, an incubation time of at least 7 days was necessary to determine the sterilization of the organism.

When the pressure became high or the pressurized time became long, the time necessary for determining the growth indicated the tendency to become long. Miyao et al. (1993) showed that the pressurization prolonged the starting time of the growth for the gram positive bacteria due to injury to the cells by high pressure. This result was similar to our result although the organism used in this study was the gram negative bacteria.

The effect of the storage period of the microbial culture on the pressure resistance of $E$. coli was investigated after the microbial culture was stored for $0-30$ day at $5^{\circ} \mathrm{C}$. The result is shown in Table 2. As the storage period of the microbial culture became longer, the pressure resistance increased. Especially, although the organism did not grow with the exception of the pressurizing time for $5 \mathrm{~min}$ when the microbial culture stored for 0 day was pressurized at 400 $\mathrm{MPa}$, the number of the growth tubes rose with the increase in the storage period. This result indicated that the pressure resistance of the organism became high during the storage. Thus, the storage period of the microbial culture (E. coli) affected the pressure resistance. The number of the growth tubes between the storage period for 15 days and that for 30 days was not different, and therefore, the microbial cultures used in this study were preserved for more than 15 days at $5^{\circ} \mathrm{C}$.

Satomi et al. (1995) indicated that the organisms incubated at the relatively high temperatures $\left(37^{\circ} \mathrm{C}\right.$ or $\left.44^{\circ} \mathrm{C}\right)$ had low pressure resistance. In our study, the shift of the temperature from $35^{\circ} \mathrm{C}$ (incubation temperature) to $5^{\circ} \mathrm{C}$ (store temperature) caused an increase in the pressure resistance. Although it is known that a change in incubation temperature affects the fluidity of the bacterium cytoplasmic membrane (Morris

Table 2. Effect of storage time of microbial culture of $E$. coli at $5^{\circ} \mathrm{C}$ on pressure resistance.

\begin{tabular}{cccccccc}
\hline \multirow{2}{*}{$\begin{array}{c}\text { St. time }^{a)} \\
\text { (days) }\end{array}$} & $\begin{array}{c}\text { Pressure } \\
\text { (MPa) }\end{array}$ & 5 & 10 & 15 & 20 & 30 & 40 \\
\hline 0 & 300 & $5^{b)}$ & 5 & 5 & 5 & 5 & 1 \\
& 400 & 2 & 0 & 0 & 0 & 0 & $-c)$ \\
3 & 300 & - & 5 & - & 5 & 2 & 1 \\
& 400 & 5 & 5 & 1 & 0 & 0 & - \\
6 & 300 & - & 5 & - & 5 & 5 & 4 \\
& 400 & 3 & 3 & 1 & 0 & 0 & - \\
15 & 300 & - & 5 & - & 5 & 5 & 5 \\
& 400 & 5 & 5 & 5 & 2 & 0 & - \\
30 & 300 & - & 5 & - & 5 & 5 & 5 \\
& 400 & 5 & 5 & 5 & 2 & 0 & - \\
\hline
\end{tabular}

E. coli cells, $4.8 \times 10^{7} \mathrm{CFU} / \mathrm{ml}$ at 0 day and $4.0 \times 10^{7} \mathrm{CFU} / \mathrm{ml}$ at 30 days storage, suspended in glucose broth were pressurized at $30^{\circ} \mathrm{C}$ and were subcultured for 7 days at $35^{\circ} \mathrm{C}$. The number of sample tubes subcultured was 5 per set.

a) Storage time at $5^{\circ} \mathrm{C}$.

${ }^{b)}$ and ${ }^{c)}$ See Table 1. 
\& Clarke, 1981), the situation of the membrane of E. coli might change even during the storage period at low temperature. As the result, the pressure resistance of $E$. coli might become high.

The effects of temperature during the pressure treatment on the pressure resistance of $E$. coli is shown in Table 3. Even though it was pressurized at $20^{\circ} \mathrm{C}$ for $40 \mathrm{~min}$, the organism was alive. However, the organism was dead under the conditions at $30^{\circ} \mathrm{C}$ for $40 \mathrm{~min}$ and at $40^{\circ} \mathrm{C}$ for $30 \mathrm{~min}$. This result showed that the pressurizing temperature influences the pressure resistance of $E$. coli in the room temperature ranges from $20^{\circ} \mathrm{C}$ to $40^{\circ} \mathrm{C}$, at which the organism can grow sufficiently. Some studies have previously been reported on the effects of temperature on pressure sterilization. For instance, when Candida parapsilosis was treated at $400 \mathrm{MPa}$ for 10 min, the survival ratio was $100 \%$ at $24^{\circ} \mathrm{C}$ and $1 \%$ at $34^{\circ} \mathrm{C}$ (Horie et al., 1992). In the case of spores of Bacillus subtilis, when the spore suspension was pressurized at $400 \mathrm{MPa}$, the death rate at $35^{\circ} \mathrm{C}$ became faster than that at $25^{\circ} \mathrm{C}$ (Okazaki et al., 1996). Furthermore, when a kind of yeast, Rhodotorula rubra, suspended in the solution of Aw 0.94 (50\% sucrose) was treated at $400 \mathrm{MPa}$ for $15 \mathrm{~min}$, less than a 2-log cycle reduction occurred at $30^{\circ} \mathrm{C}$ and a $7-\log$ cycle was inactivated at $45^{\circ} \mathrm{C}$, though the number of cells was not decreased at $25^{\circ} \mathrm{C}$ (Oxen \& Knorr, 1993). These results indicate that, even if the species of organisms are different, room temperatures between $20^{\circ} \mathrm{C}$ and $40^{\circ} \mathrm{C}$ affect pressure resistance sufficiently.

It is known that the sample temperature increases as a result of the adiabatic compression when the sample is pressurized within a relatively short time. This phenomenon is very important to understand the pressure resistance of organisms, because the pressure resistance is affected even by room temperature as indicated in Table 3. The temperature and pressure history curves of the sample directly measured during the pressure treatments are shown in Fig. 1. The sample temperature rose about $8^{\circ} \mathrm{C}$ from the initial temperature for each case pressurized up to $400 \mathrm{MPa}$ at $20^{\circ} \mathrm{C}, 30^{\circ} \mathrm{C}$ and $40^{\circ} \mathrm{C}$, and a period of more than $60 \mathrm{~s}$ was necessary for it to return to the initial temperature. After the pressure treatments, the sample temperature dropped about $13^{\circ} \mathrm{C}$ as a result of the adiabatic expansion during the release of the pressure. So, all samples shown in Table 3 definitely trace the temperature history curves such as Fig. 1 during the pressure treatments. Thus, the maximum and minimum temperatures of the sample treated at $20^{\circ} \mathrm{C}$ are predicted to be $28^{\circ} \mathrm{C}$ and to be $7^{\circ} \mathrm{C}$, respectively.

The temperature history curve of the sample measured directly during pressurizing had rarely been indicated in the

Table 3. Effect of temperture during pressurizing at $400 \mathrm{MPa}$ on pressure resistance of $E$. coli.

\begin{tabular}{ccccccc}
\hline \multirow{2}{*}{$\begin{array}{c}\text { Pressure } \\
(\mathrm{MPa})\end{array}$} & $\begin{array}{c}\text { Temperature } \\
\left({ }^{\circ} \mathrm{C}\right)\end{array}$ & 10 & 15 & 20 & 30 & 40 \\
\hline 400 & 20 & $5^{a)}$ & 5 & 5 & 5 & 5 \\
& 30 & 5 & 5 & 5 & 2 & 0 \\
& 40 & 5 & 5 & 5 & 0 & 0 \\
\hline
\end{tabular}

Initial population of $E$. coli was $9.1 \times 10^{6} \mathrm{CFU} / \mathrm{ml}$.

a) Number of positive growth tubes. previous reports, even though the treatment temperature was mentioned in the reports. Therefore, the following experiment was arranged to clarify the effect of the increase in the sample temperature as a result of adiabatic compression. The microbial suspension of $E$. coli cells is pressurized for only 30 $\mathrm{s}$ at $400 \mathrm{MPa}$, and then the sample temperature rises to about $8^{\circ} \mathrm{C}$ from the initial level. This rising temperature is almost maintained during the $30 \mathrm{~s}$ as shown in Fig. 1, and therefore the rising temperature was utilized as the real pressurized temperature instead of the initial value. $E$. coli suspensions were pressurized at $400 \mathrm{MPa}$ at the initial temperatures ranging from $10^{\circ} \mathrm{C}$ to $50^{\circ} \mathrm{C}$; the measured maximum sample temperatures and the numbers of survival cells are indicated in Table 4.

Although the survival number at $20^{\circ} \mathrm{C}$ hardly decreased, the survival number at $10^{\circ} \mathrm{C}, 30^{\circ} \mathrm{C}$ and $40^{\circ} \mathrm{C}$ decreased to one-twenty, $3 \log$ cycles and $6 \log$ cycles, respectively. At $50^{\circ} \mathrm{C}$, the surviving organism was not detected. Each real pressurized temperature was the initial one + about $8-9^{\circ} \mathrm{C}$ as shown in Table 4, and the temperature expressing the highest pressure resistance was $28^{\circ} \mathrm{C}$. When the treatment temperatures become higher or lower than $28^{\circ} \mathrm{C}$, the pressure resistance became lower than the result at $28^{\circ} \mathrm{C}$. Based on this result, the temperature region showing the highest pressure resistance is thought to exist at around $28^{\circ} \mathrm{C}$. Furthermore, if the pressurized treatments are carried out at below $18^{\circ} \mathrm{C}$ or

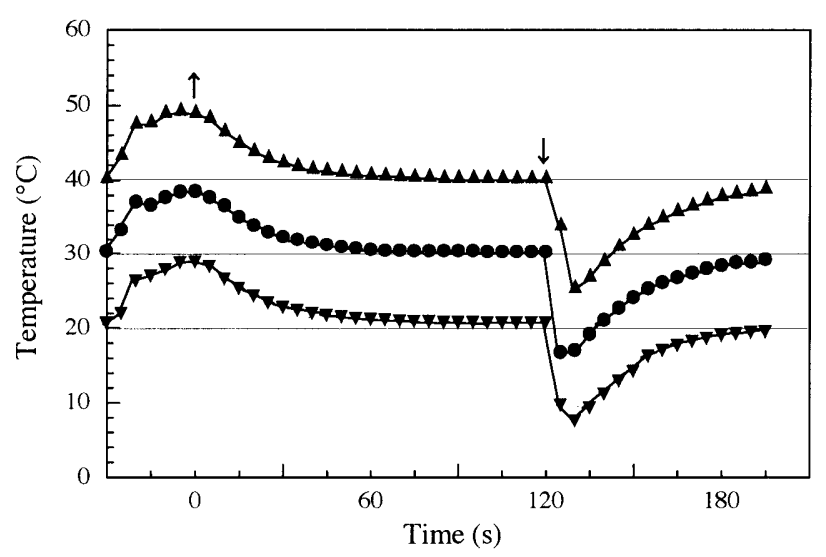

Fig. 1. Temperature history curves of sample suspension during the pressure treatments at $400 \mathrm{MPa}$ for $120 \mathrm{~s}$. Symbols $\left(\nabla 20^{\circ} \mathrm{C},-30^{\circ} \mathrm{C}, \boldsymbol{\Delta} 40^{\circ} \mathrm{C}\right)$. The up-arrow is the starting point of the pressure treatments and the down-arrow is the end point.

Table 4. Effect of temperature increase during pressure treatment on E. coli cells at $400 \mathrm{MPa}$.

\begin{tabular}{ccc}
\hline $\begin{array}{c}\text { Initial temperature } \\
\left({ }^{\circ} \mathrm{C}\right)\end{array}$ & $\begin{array}{c}\text { Sample temperature } \\
\left({ }^{\circ} \mathrm{C}\right)\end{array}$ & $\begin{array}{c}\text { Survivors } \\
(\mathrm{CFU} / \mathrm{ml})\end{array}$ \\
\hline 10.2 & 18.1 & $1.7 \times 10^{5}$ \\
20.2 & 28.4 & $1.9 \times 10^{6}$ \\
30.2 & 38.5 & $3.5 \times 10^{3}$ \\
40.1 & 49.0 & $5.0 \times 10$ \\
50.1 & 59.1 & no detection \\
\hline
\end{tabular}

The times increasing, holding and decreasing pressure were $30 \mathrm{~s}, 10 \mathrm{~s}$, and 10 $\mathrm{s}$, respectively. Initial population of $E$. coli was $2.6 \times 10^{6} \mathrm{CFU} / \mathrm{ml}$. 
above $38^{\circ} \mathrm{C}$ as the real pressurized temperatures, the pressure resistance of organisms is probably revealed to be lower. This result is in agreement with those of Horie et al (1992) and Okazaki et al. (1996) as mentioned above.

Microbes (14 genera), 6 of which are gram negative bacteria, 5 of which are gram positive ones and 3 of which are yeasts and fungi, were pressurized under the following conditions; the microbe suspensions preserved for more than 15 days at $5^{\circ} \mathrm{C}$ were used as the samples. The incubation period to determine the growth after pressurizing was 7 days. The pressurizing conditions were at $300 \mathrm{MPa}, 400 \mathrm{MPa}$ and $500 \mathrm{MPa}$ for $20 \mathrm{~min}$ at $20^{\circ} \mathrm{C}$ (initial temperature), and the maximum rising temperature of the sample is then measured to be about $28^{\circ} \mathrm{C}$.

Table 5 shows the results. Acinetobacter sp., P. fluorescens and $V$. parahaemolyticus (all gram negative), and Saccharomyces cerevisiae were dead at $300 \mathrm{MPa}$, although gram positive bacteria were all alive at that pressure. At $400 \mathrm{MPa}$, S. Typhimurium, M. morganii, L. mesenteroides and $C$. parapsilosis were dead. At $500 \mathrm{MPa}, E$. coli and L. plantar ump were dead. However, S. aureus, E. faecalis and Corynebacterium $\mathrm{sp}$. and $N$. hiratsukae (ascospores) survived even at $500 \mathrm{MPa}$ and these organisms except for $N$. hiratsukae were all gram positive bacteria.

Among these results, the bacteria possessing the highest pressure resistance were $S$. aureus, E. faecalis and Corynebacterium sp., all of which were cocci as well as gram positive bacteria. It is known that the cell walls of gram positive bacteria are thicker and firmer than those of the gram negative ones (Roger et al., 1976), and therefore the difference in cell wall structure may directly affect the pressure resistance. Furthermore, the fact that the shape of the bacteria is spherical may also increase the structural strength against high pressure. In the previous studies, it was indicated that $S$. aureus, E. faecalis, and Corynebacterium sp. have the

Table 5. Pressure resistance of 14 genera of bacteria and fungi.

\begin{tabular}{lllll}
\hline \multirow{2}{*}{ Genera } & Initial pupulations & \multicolumn{3}{c}{ Pressure $(\mathrm{MPa})^{a)}$} \\
\cline { 2 - 5 } & $(\mathrm{CFU} / \mathrm{ml})$ & 300 & 400 & 500 \\
\hline Gram negative bacteria & & & & \\
Escherichia coli & $1.3 \times 10^{7}$ & $5^{b)}$ & 5 & 0 \\
Salmonella typhimurium & $3.3 \times 10^{7}$ & 5 & 0 & 0 \\
Morganella morganii & $2.2 \times 10^{7}$ & 5 & 0 & 0 \\
Pseudomonas ftuorescens & $3.2 \times 10^{7}$ & 0 & 0 & 0 \\
Vibrio parahaemolyticus & $3.5 \times 10^{6}$ & 0 & 0 & 0 \\
Acinetobacter sp. & $4.8 \times 10^{7}$ & 0 & 0 & 0 \\
Gram positive bacteria & & & & \\
Staphylococcus aureus & $8.2 \times 10^{6}$ & 5 & 5 & 5 \\
Enterococcus faecalis & $5.9 \times 10^{7}$ & 5 & 5 & 5 \\
Lactobacillus plantarum & $2.4 \times 10^{7}$ & 5 & 5 & 5 \\
Leuconostoc mesenteroides & $9.4 \times 10^{7}$ & 4 & 0 & 0 \\
Corynebacterium sp. & $1.1 \times 10^{7}$ & 5 & 5 & 5 \\
Fungi & & & & \\
Saccharomyces cereviseae & $-c)$ & 0 & 0 & 0 \\
Candida parapsilosis & $1.0 \times 10^{6}$ & 5 & 0 & 0 \\
Neosartorya hiratsukae ${ }^{d)}$ & $2.4 \times 10^{3}$ & 5 & 5 & 5 \\
\hline
\end{tabular}

a) Pressurized at $20^{\circ} \mathrm{C}$ for $20 \mathrm{~min}$.

${ }^{b)}$ Number of positive growth tubes.

${ }^{c}$ Not counted.

${ }^{d)}$ Ascospores. pressure resistance even at $600 \mathrm{MPa}$ (Ohmori \& Shigehisa, 1990; Miyao et al. 1993). Also in our study, these bacteria were alive at $500 \mathrm{MPa} \cdot 20^{\circ} \mathrm{C} \cdot 20 \mathrm{~min}$. Consequently, it will be necessary to pressurize at higher than $500 \mathrm{MPa}$ in order to sterilize them at $20^{\circ} \mathrm{C}$.

E. coli was dead under the conditions of $400 \mathrm{MPa} \cdot 20^{\circ} \mathrm{C} \cdot$ $10 \mathrm{~min}$ (Kajiyama et al. 1993) and decreased to $10^{2} \mathrm{CFU} / \mathrm{ml}$ from $10^{8} \mathrm{CFU} / \mathrm{ml}$ under the same conditions (Arroyo et al, 1997). Our results indicate that $E$. coli was alive at $400 \mathrm{MPa}$. $20^{\circ} \mathrm{C} \cdot 20 \mathrm{~min}$ and dead at $500 \mathrm{MPa} \cdot 20^{\circ} \mathrm{C} \cdot 20 \mathrm{~min}$ and so had higher pressure resistance than that shown in the results of the previous reports.

$V$. parahaemolyticus was rapidly killed by the pressure condition at $1700 \mathrm{~atm}(172 \mathrm{MPa}) \cdot 23^{\circ} \mathrm{C}$ (Styles et al., 1991). In our results, the microbe was inactivated by the pressurization at $300 \mathrm{MPa} \cdot 20^{\circ} \mathrm{C} \cdot 20 \mathrm{~min}$.

S. typhimurium decreased to less than 3 log cycles at 3400 atm (344 MPa) for $20 \mathrm{~min}$ (the pressurizing temperature is not shown, Metrick et al, 1989) and to $10^{2} \mathrm{CFU} / \mathrm{ml}$ from $10^{8}$ $\mathrm{CFU} / \mathrm{ml}$ at $400 \mathrm{MPa} \cdot 20^{\circ} \mathrm{C} \cdot 10 \mathrm{~min}$ (Arroyo et al., 1997). Our results revealed that the organism was living at $300 \mathrm{MPa} \cdot$ $20^{\circ} \mathrm{C} \cdot 20 \mathrm{~min}$ but was dead at $400 \mathrm{MPa} \cdot 20^{\circ} \mathrm{C} \cdot 20 \mathrm{~min}$.

The ascospores (spores in a ascus produced during a teleomorph) of $N$. hiratsukae survived at $500 \mathrm{MPa} \cdot 20^{\circ} \mathrm{C} \cdot 20$ min, and our results indicated a relatively higher value than the pressure resistance of other fungi. The generation of ascospores might possess a higher pressure resistance than others such as conidia and mycelia.

In conclusion, some factors affecting pressure resistance existed in the pressurizing procedure. That is, an incubation time of the pressurized microbe of 7 days was needed to determine the sterilization. The microbial culture stored for 15 days at $5^{\circ} \mathrm{C}$ had a higher pressure resistance than the culture just after cultivation. The increase of sample temperature as a result of adiabatic compression affected the pressure resistance of $E$. coli considerably, and the pressure treatment at $20^{\circ} \mathrm{C}$ showed the highest pressure resistance. Under these conditions, the pressure resistance of microbes (14 genera) was investigated at pressures ranging from $300 \mathrm{MPa}$ to $500 \mathrm{MPa}$ at $20^{\circ} \mathrm{C}$ for $20 \mathrm{~min}$. Three genera (all gram negative) of them were dead at below $400 \mathrm{MPa}$, and 3 genera (all gram positive) of them survived even at $500 \mathrm{MPa}$, indicating that it is probable that gram positive organisms have higher pressure resistance than gram negative ones.

\section{References}

Arroyo, G., Sanz, P.D. and Prestamo, G. (1997). Effect of high pressure on the reduction of microbial populations in vegetables. $J$. Appl. Microbiol., 82, 735-742.

Hayashi, R. (1989). Application of high pressure to food processing and preservation, Philosophy and development. In "Engineering and Food," ed. by W.E.L. Spiess and H. Schubert, Vol. 2, 815-826.

Hite, B.H. (1889). The effect of pressure in the preservation of milk. Bull. 58, 15-35. w. Va. Univ. Agric. Exp. Sta., Mogantown.

Horie, Y., Kimura, K., Ida, M., Yoshida, Y. and Ohki, K. (1992). Identification and pressure-sterilization of a candida strain resistant to high pressure. Nippon Nogeikagaku Kaishi, 65, 975-980 (in Japanese).

Kajiyama, N., Akizumi, K., Abei, K., Nagata, M., Egashira, T. and Miyake, Y. (1993). Sterilization of Escherichia coli by high pressure. Nippon Shokuhin Kogyo Gakkaishi, 40, 406-413 (in Japanese). 
Metrick, C., Hoover, D.G. and Farkas, D.F. (1989). Effects of high hydrostatic pressure on heat-resistant and heat-sensitive strains of Salmonella. J. Food Sic., 54, 1547-1549.

Miyao, S., Shindoh, T., Miyamori, K. and Arita, T. (1993). Effects of high pressurization on the growth of bacteria derived from surimi. Nippon Shokuhin Kogyo Gakkaishi, 40, 478-484 (in Japanese).

Morris, G.J. and Clarke, A. (1981). "Effect of low temperature on biological membranes" ed. by Academic Press, New York, p. 41-53.

Ohmori, T. and Shigehisa, T. (1990). Application of high hydrostatic pressure to the processing of meat and meat products. PressureProcessed Food, Kyoto, Japan, 131-139 (in Japanese).

Okazaki, T., Yoneda, T. and Suzuki, K. (1994). Combined effects of temperature and pressure on sterilization of Bacillus subtilis spores. Nippon Shokuhin Kogyo Gakkaishi, 41, 536-541 (in Japanese).

Okazaki, T., Maeshige, S. and Suzuki, K. (1996). Combined effects of temperature and pressure on inactivation of heat-resistant bacteria. High Pressure Bioscience and Biotechnology, Kyoto, Japan, pp. 415-418.

Oxen, P. and Knoor, D. (1993). Baroprotective effects of high sokute concentrations against inactivation of Rhodotorula rubra. Food Sci. Technol., 45, 153-160.

Roger, S., Edward, A. and John, I. (1976). "The microbial world (4th edition)," Prentice-Hall Inc., New Jersey.

Satomi, M., Yamaguchi, T., Okuzumi, M. and Fujii, T. (1995). Effect of several conditions on the recovery of pressure-injured bacteria. Shokuhin Eiseigaku Zasshi, 36, 344-351 (in Japanese).

Styles, M.F., Hoover, D.G. and Farkas, D.F. (1991). Response of Listeria monocytogenes and Vibrio parahaemolyticus to high hydrostatic pressure. J. Food Sic., 56, 1404-1407. 